\title{
Bioinformatics Analysis of Four Gallinacin Genes for Immunity Traits in Chickens
}

\author{
Saleh, M. S $^{1}$., Khalil, M. H ${ }^{1}$., Iraqi, M. $\mathbf{M}^{1}$., Camarda, A. $^{2}$ \\ ${ }^{1}$ Department of Animal Production, Faculty of Agriculture at Moshtohor, Benha University, 13736, Egypt \\ ${ }^{2}$ Avian Pathology Section, Department of Veterinary Medicine, University of Bari, \\ 70010 Valenzano - Bari, Italy \\ Corresponding author email: maher.khalil@ fagr.bu.edu.eg
}

\begin{abstract}
Four candidate gallinacin polymorphic genes were sequenced in one direction from Fayoumi (F), Rhode Island Red $(\mathrm{R})$ and their crosses $\left(1 / 2 \mathrm{R}^{1} / 2 \mathrm{~F}\right.$ and $\left.1 / 2 \mathrm{~F}^{1} / 2 \mathrm{R}\right)$. Pairwise bioinformatics sequencing of $G A L$ genes of the parents relative to $F_{1}$ generation was identified. Bioinformatics analyses of GAL genes showed many sequence variations. The pairwise sequence alignment between $\mathrm{F}$ and $1 / 2 \mathrm{~F}^{1} / 2 \mathrm{R}$ were identified, being 17 SNPs with identity ratio of $97 \%$ for GAL 2 gene, many SNPs and gaps with low identity ratio of $50 \%$ for GAL 3 gene, ten SNPs with identity ratio of $98 \%$ for $G A L 4$ gene and 18 SNPs with identity ratio of $97 \%$ for $G A L 5$ gene. Between $\mathrm{F}$ and $1 / 2 \mathrm{R} 1 / 2 \mathrm{~F}$ there were 11 SNPs with identity ratio of $98 \%$ for GAL 2 gene, 15 SNPs with identity ratio of $98 \%$ for GAL 3 gene, 20 SNPs with identity ratio of $96 \%$ for GAL 4 gene and many SNPs with low identity ratio of $50 \%$ for GAL 5 gene. Between $\mathrm{R}$ and $1 / 2 \mathrm{~F}^{1 / 2} \mathrm{R}$, the sequence in GAL 2 gene were 12 SNPs with identity ratio of $98 \%, 38$ SNPs with identity ratio of $94 \%$ in GAL 3 gene, many SNPs and gaps with low identity ratio of 50\% in GAL 4 gene and 37 SNP with identity ratio of $90 \%$ in GAL 5 gene. The sequence between $\mathrm{R}$ and $1 / 2 \mathrm{R} 1 / 2 \mathrm{~F}$ being 21 SNPs with identity ratio of $96 \%$ for GAL 2 gene and many SNPs and gaps with low identity ratio of 50\% for GAL 3 gene. The gene SNPtrait associations are not identical among all genes in the gallinacins cluster. Bioinformatics analyses of $G A L$ genes showed many sequence variations and mutations in intronic regions. The SNPs identified in gallinacin genes could be used in marker assisted selection in breeding program to enhance immune responses to Salmonella disease in chickens.
\end{abstract}

Keywords: Chickens, Bioinformatics, Gallinacin genes, Salmonella, Immune response.

\section{Introduction}

In recent years, advances in molecular technology have created a new horizon for the genetic improvement of disease-resistant traits in poultry Detection of associations between candidate genes or markers and Salmonella bacterial burden could also lead to improve disease resistance in chickens (Rothschild, 1997). The identification of direct or indirect molecular markers for these traits would facilitate the use of these markers in selection or in gene introgression (Wakchaure et al., 2015). However, Salmonella typhimurium and Salmonella enteritidis are acute systemic diseases in young chicks (Friedman et al. 2003). In this concept, few reports on Salmonella serovars distribution in broiler farms were documented (Ammar et al., 2009; Abd El-Ghany et al., 2012; El-Safey, 2013). Beta-defensins belong to a family of defensins which is ataxonomic group of cationic antimicrobial peptides (AMPs) with broadspectrum antimicrobial activity against various microorganisms, fungi, and viruses (Lai and Gallo, 2009). Gallinacins are cysteine-rich antimicrobial peptides characterized by six cysteine residues, which form three pairs of disulfide bridges (Sugiarto and Yu 2004). These are relatively small antimicrobial peptides, typically less than 100 amino acids in size, which possess a broad range of antimicrobial activity (Sugiarto and Yu 2004). Gallinacins are functional analogues of the mammalian beta-defensins and play an important role in the innate immunity against microbial infections in chickens. In chickens, gallinacin genes 1 to 13 have been mapped within an 86-kb region of chromosome 3 and each gallinacin gene possesses the same genomic structure of four short exons that are separated by three introns of various lengths (Xiao et al., 2004). These gallinacins genes are abundant in cells that are involved in the innate immune system response against microbial infections (Ganz, 2003; Xiao et al., 2004; Hasenstein et al., 2006; Hasenstein and Lamont, 2007; Morammazi and Habibi, 2017) and they exhibit wider range of antimicrobial activity against both gram-positive and gram-negative bacteria (Higgs $\boldsymbol{e t}$ al., 2005). Since, planning to use genetic selection and breeding program for resistance to disease using molecular markers would result in a resistance population and reduce the price of treatment (Pruthviraj et al., 2016). In breeding programs, when using popular techniques such as those relying upon to polymerase chain reaction (PCR), it is better to consider molecular markers that are close to healthrelated peptides' ordination. To date, some studies have been conducted to find the connection between poultry genome and poultry diseases (Kramer $\boldsymbol{e t}$ al., 2003). However, beta-defensin genes have been neglected. The main objective of the present study was to identify the SNPs of gallinacins genes in parental breeds of Fayoumi (F) and Rhode Island Red breed (R) and their crosses $1 / 2 \mathrm{R}^{1 / 2} \mathrm{~F}$ and $1 / 2 \mathrm{~F}^{1 / 2} \mathrm{R}$ using bioinformatics analysis.

\section{Materials and methods}

\section{Breeding plan and management}


Bioinformatics analysis was performed in an crossbreeding experiment involving Fayoumi (F) and Rhode Island Red $(\mathrm{R})$ and their crosses $\left(1 / 2 \mathrm{R}^{1 / 2} \mathrm{~F}\right.$ and $\left.1 / 2 \mathrm{~F}^{1 / 2} \mathrm{R}\right)$. The details of the crossbreeding experiment of the studied populations were described in the pervious manuscript (Saleh et al., 2020).

The chicks were kept under similar hygienic and environmental conditions, vaccinated against Newcastle and Gumboro disease, housed under continuous fluorescent lighting $\left(10\right.$ watt $\left./ \mathrm{m}^{2}\right)$ and provided un-medicated corn soybean-based meal diet (not containing antibiotics, coccidiostats, or growth promoters). Fresh water was provided for the chicks ad libitum. Chicks produced from all genetic groups were fed ad libitum on diet containing $21 \%$ protein and $2700 \mathrm{kcal} / \mathrm{kg}$ during the growing period (from hatch up to 10 weeks of age). Minerals and vitamins were adequately supplied to cover the chicks' requirements according to NRC (1994).

\section{Blood sampling and DNA extraction}

Ninety-six chicks belonging to four chicken genetic groups ( 24 chicks from each group of $\mathrm{F}, \mathrm{R}$, $1 / 2 \mathrm{~F}^{1 / 2} \mathrm{R}$ and $1 / 2 \mathrm{R}^{1 / 2} \mathrm{~F}$ ) were used in the molecular genetic analyses. The blood samples were collected from pedigreed chicks with the least relationship to decrease the genetic similarity between the genotyped chicks. Approximately 3-5 $\mathrm{ml}$ venous blood sample per chick was collected from the wing vein by a 2 gauge 1.5-injection needle into tubes containing
EDTA as anticoagulant. Genomic DNA was extracted from Whole Blood Genomic DNA Purification Mini Kit (Cat No. \#K0781, Thermo Scientific). The laboratorial analyses for molecular biology were carried out in the Labs of Genetics Department, Faculty of Agriculture, Benha University, Egypt, and Avian Pathology Section, Department of Veterinary Medicine, University of Bari, Italy since April to September 2017.

\section{PCR amplification}

Preliminarily, the primer sequences were assessed insilico (http://insilico.ehu.es/PCR/) and each gene of Gal 2, Gal 3, Gal 4 and Gal 5 (each coding for a respective avian beta-defensin) was characterized by amplifying a portion using the proper primer pair listed in Table 1 (Hasenstein et al., 2006; Saleh, 2019). On chromosome 3 , PCR amplifications were carried out in $50 \mu l$ reaction mixture composed of 4 $\mu l$ genomic DNA $(100 \mathrm{ng} / \mu l)$ as a template, $50 \mathrm{pmol}$ of each primer, $2.5 \mathrm{mM}$ dNTP' (dATP, dCTP, dTTP and dGTP; ABgene, Surrey, UK), 10X PCR buffer, 25 $\mathrm{mM} \mathrm{MgCl}_{2}$, and 2.5 unit Taq DNA polymerase. After electrophoresis, the gel was stained with ethidium bromide $0.5 \mu \mathrm{g} / \mathrm{ml}$. Gallinacin genes fragments were visualized by using a UV transilluminator and documented in Gel Doc ${ }^{\mathrm{TM}} \mathrm{XR}^{+}(\mathrm{BIO}-\mathrm{RAD})$. The PCR products werepurified using QIAquick PCR purification kit (Qiagen,Inc.) and the purified products were used in the subsequent sequencing reactions.

Table 1 Primer sequence of Gal genes in chromosome 3

\begin{tabular}{|c|c|c|c|}
\hline Gene & Primer sequences (forward/reverse) & $\begin{array}{l}\text { PCR Product size } \\
\text { (bp) }\end{array}$ & $\begin{array}{l}\text { GenBank } \\
\text { accession No. }\end{array}$ \\
\hline Gal 2 & $\begin{array}{l}\text { 5'-GGCACAAAGGGTAAAGTATGG -3' } \\
\text { 5'- GAGGGGTCTTCTTGCTGCTGA -3' }\end{array}$ & 583 & (AY621317) \\
\hline Gal 3 & $\begin{array}{l}\text { 5'- GCACCACAAGAAGCCCAGGAA -3' } \\
\text { 5'- ААСТCCAGCCCTTACCACTCA -3' }\end{array}$ & 664 & (AY621318) \\
\hline Gal 4 & $\begin{array}{l}\text { 5'- TGGGGATCTTAGAGGTCTTTT -3' } \\
\text { 5'- TTTTCCACAGATATTGCTTTT -3' }\end{array}$ & 600 & (AY621319) \\
\hline Gal 5 & $\begin{array}{l}\text { 5'CTCCCAGCAAGAAAGGAACCTG -3' } \\
\text { 5'-CACAGTCCTGGGGTAATCCTCG-3' }\end{array}$ & 623 & $(\mathrm{AY} 621320)$ \\
\hline
\end{tabular}

\section{Sequencing of $G A L$ genes}

The purified PCR fragment was ligated in pGEMR-T Easy Vector Systems (Promega, Cat. \#: A1360) according to the manufacturer's instructions. The purified plasmids were examined and sequenced using electrophoresis on $1.5 \%$ agarose gel using GeneRulerTM 1 kb DNA Ladder (Cat. \#: SM0313) of Macrogen Company (South Korea) to confirm the recombinant plasmids. The obtained sequences for GAL 2, GAL 3, GAL 4 and GAL 5 genes were examined for vector contamination using the VecScreen tool (http:// www.ncbi.nlm.nih.gov/tools/vecscreen). While Jalview software was used to show single nucleotide polymorphisms (SNPs) resulted from the alignment of obtained sequences (http://www.jalview.org/). The obtained sequences were submitted in GenBank under the accession numbers.

Bioinformatics sequencing and pairwise alignment of GALlinacin genes

PCR products of GAL 2 (583 bp), GAL 3 (664 bp), GAL 4 (600 bp) and GAL 5 (623 bp) genes were partially sequenced and registered for the genetic groups of $F, R, 1 / 2 F^{1} / 2 R$ and $1 / 2 R^{1} / 2 F$ in the NCBI database under the following accession numbers: MH000270.1, MH000271.1, MH000272.1 and MH000273.1 for GAL 2 gene; MH000274.1, MH000275.1, MH000276.1 and MH000277.1 for GAL 3 gene; MH000278.1, MH000279.1, MH000280.1 and MH000281.1 for GAL 4 gene; MH000282.1, MH000283.1, MH000284.1 and MH000285.1 for GAL 5 gene. The VecScreen 
database analysis, revealed no contamination with vector sequences. Assessment of the genetic variability in the studied populations was performed via identifying SNPs and gaps in GAL 2, GAL 3, GAL 4 and $G A L 5$ genes in terms of sequences of $\mathrm{F}_{1}$ chicken and the parental sequences.

\section{Results and discussion}

Pairwise sequence of $G A L$ genes of the parents relative to $F_{1}$ generation

The pairwise sequence alignment of $G A L$ genes of the parents compared with $\mathrm{F}_{1}$ generation is illustrated in Table 2 and Figures 1, 2, 3 and 4. The sequence variations of $G A L$ genes revealed that the genetic backgrounds in the studied genetic groups of chickens are highly polymorphic.

Table 2 Pairwise sequence alignment of $G A L$ genes of the parents compared with F1 generation

\begin{tabular}{|c|c|c|c|c|}
\hline Gene & Pairwise genetic groups & No. of SNPs & No. of gaps & Identity ratio ( \%) \\
\hline \multirow[t]{4}{*}{$G A L 2$} & F with $1 / 2 \mathrm{~F}^{1 / 2} \mathrm{R}$ & 17 & - & 97 \\
\hline & F with $1 / 2 R^{1} / 2 F$ & 11 & 3 & 98 \\
\hline & $\mathrm{R}$ with $1 / 2 \mathrm{~F}^{1} / 2 \mathrm{R}$ & 12 & - & 98 \\
\hline & $R$ with $1 / 2 R^{1} / 2 F$ & 21 & 1 & 96 \\
\hline \multirow[t]{4}{*}{ GAL 3} & F with $1 / 2 \mathrm{~F}^{1 / 2} \mathrm{R}$ & Many & Many & 50 \\
\hline & F with $1 / 2 R^{1} / 2 F$ & 15 & - & 98 \\
\hline & $\mathrm{R}$ with $1 / 2 \mathrm{~F}^{1} / 2 \mathrm{R}$ & 38 & 1 & 94 \\
\hline & $R$ with $1 / 2 R^{1} / 2 F$ & Many & Many & 50 \\
\hline \multirow{4}{*}{$G A L 4$} & $\mathrm{~F}$ with $1 / 2 \mathrm{~F}^{1} / 2 \mathrm{R}$ & 10 & 1 & 98 \\
\hline & $\mathrm{F}$ with $1 / 2 \mathrm{R}^{1} / 2 \mathrm{~F}$ & 20 & - & 96 \\
\hline & $\mathrm{R}$ with $1 / 2 \mathrm{~F}^{1} / 2 \mathrm{R}$ & Many & Many & 50 \\
\hline & $\mathrm{R}$ with $1 / 2 \mathrm{R}^{1 / 2 \mathrm{~F}}$ & Many & Many & 50 \\
\hline \multirow[t]{4}{*}{ GAL 5} & F with $1 / 2 \mathrm{~F}^{1 / 2} \mathrm{R}$ & 18 & - & 97 \\
\hline & F with $1 / 2 R^{1} / 2 F$ & Many & Many & 50 \\
\hline & $\mathrm{R}$ with $1 / 2 \mathrm{~F}^{1} / 2 \mathrm{R}$ & Many & Many & 50 \\
\hline & $\mathrm{R}$ with $1 / 2 \mathrm{R}^{1 / 2} \mathrm{~F}$ & 37 & 2 & 90 \\
\hline
\end{tabular}

These high genetic variations were located in the regions associated with the innate immune response to caecal bacteria (Sugiarto and Yu, 2004; Higgs et al., 2005; Morammazi and Habibi, 2017) and having the role in increasing the resistance to diseases (BarShira and Friedman, 2006). It is essential to consider further research in the local poultry resources because these indigenous populations can have valuable genes pool or major supply of genes resistant to the local harsh climate, i.e. the genetic groups studied could be considered in poultry breeding programs of genetic selection especially for disease resistance.

In terms of gallinacin 2 genomic DNA sequence, a 583 bp product was amplified and 17 SNPs were identified between $\mathrm{F}$ and $1 / 2 \mathrm{~F}^{1} / 2 \mathrm{R}$ with high identity ratio of $97 \%$ (Fig. 1), 11 SNPs and three gaps between $\mathrm{F}$ and $1 / 2 \mathrm{R} 1 / 2 \mathrm{~F}$ with high identity ratio of $98 \%$ (Fig. 2), 12 SNPs between $\mathrm{R}$ with $1 / 2 \mathrm{~F}^{1} / 2 \mathrm{R}$ cross with also high identity ratio of $98 \%$ (Fig. 3) and 21 SNPs and one gap between $\mathrm{R}$ and $1 / 2 \mathrm{R} 1 / 2 \mathrm{~F}$ cross with high identity ratio of $96 \%$ (Fig. 4). 


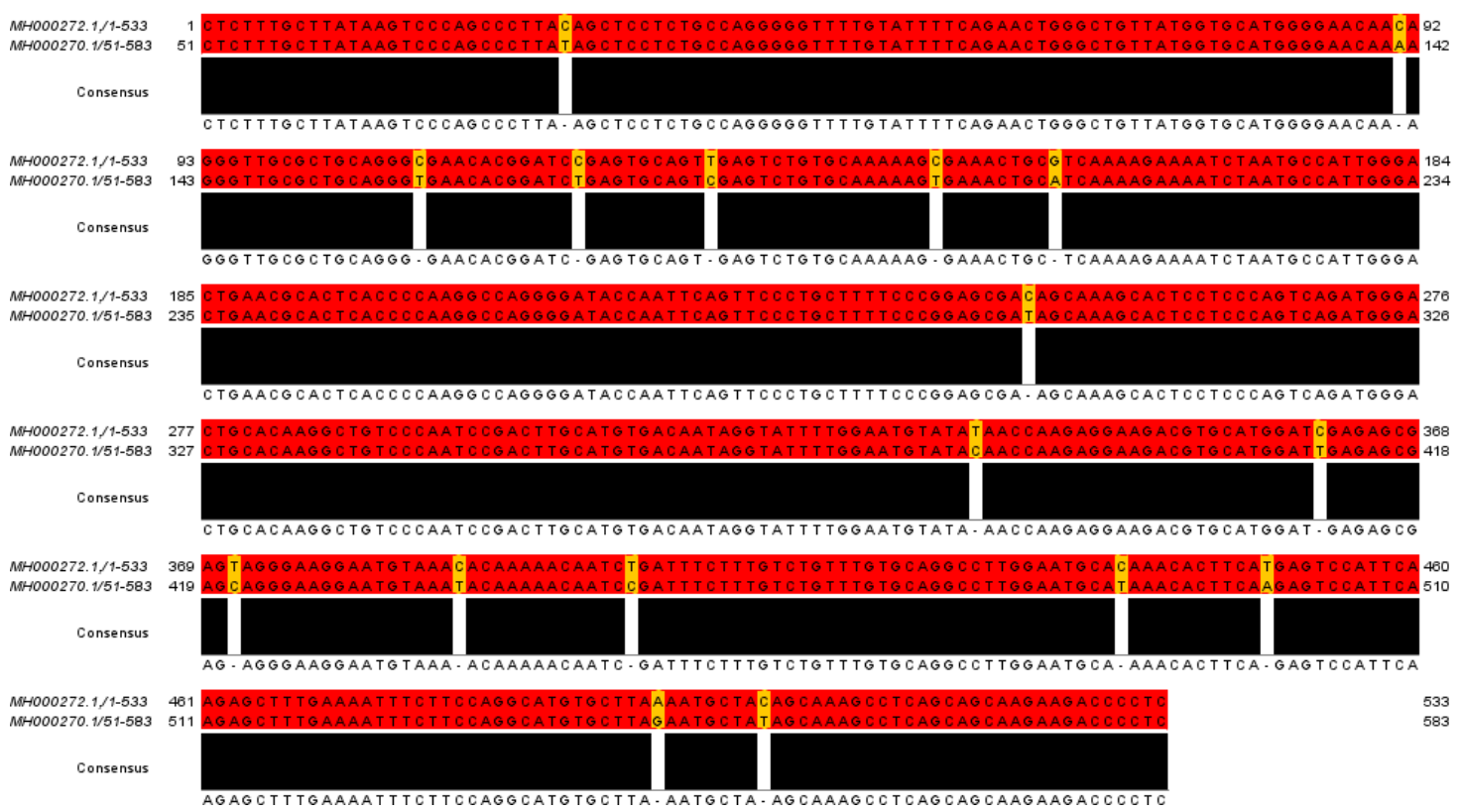

Fig. 1: Pairwise sequence alignment of $G A L 2$ gene between $F$ breed and $1 / 2 \mathrm{~F}^{1 / 2} \mathrm{R}$ cross.

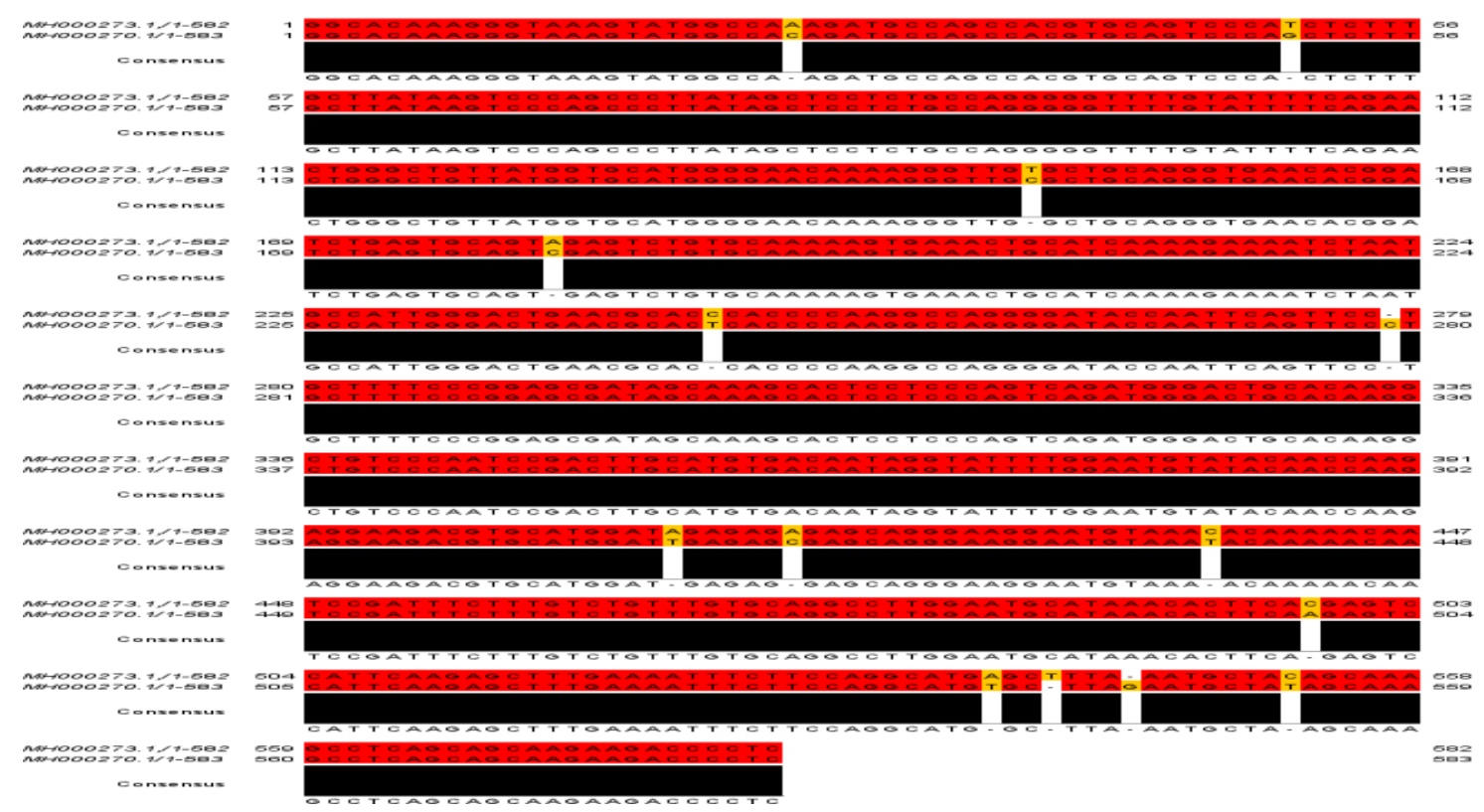

Fig. 2: Pairwise sequence alignment of $G A L 2$ gene between $\mathrm{F}$ breed and $1 / 2 \mathrm{R} 1 / 2 \mathrm{~F}$ cross. 


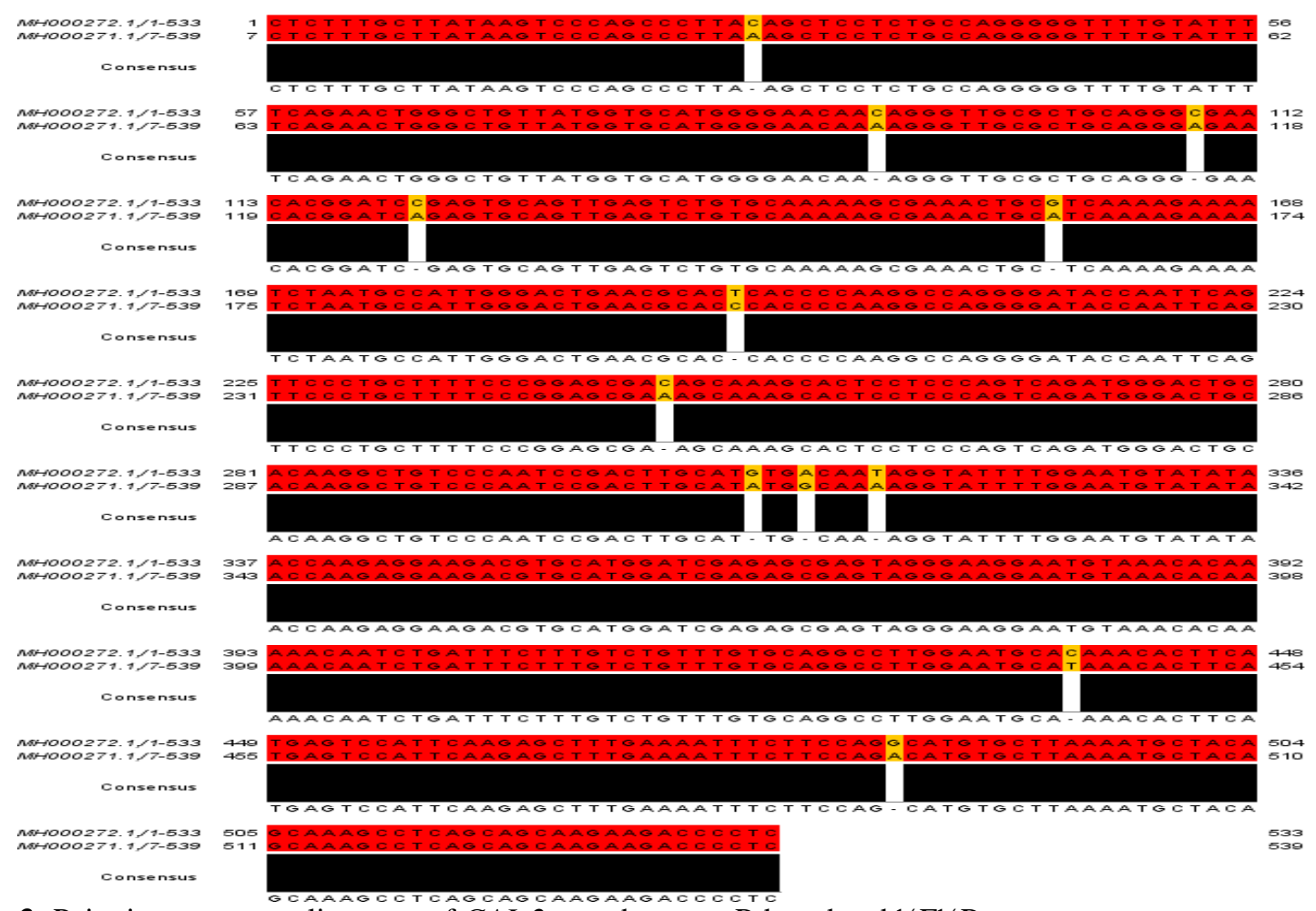

Fig. 3: Pairwise sequence alignment of $G A L 2$ gene between $\mathrm{R}$ breed and $1 / 2 \mathrm{~F} 1 / 2 \mathrm{R}$ cross.

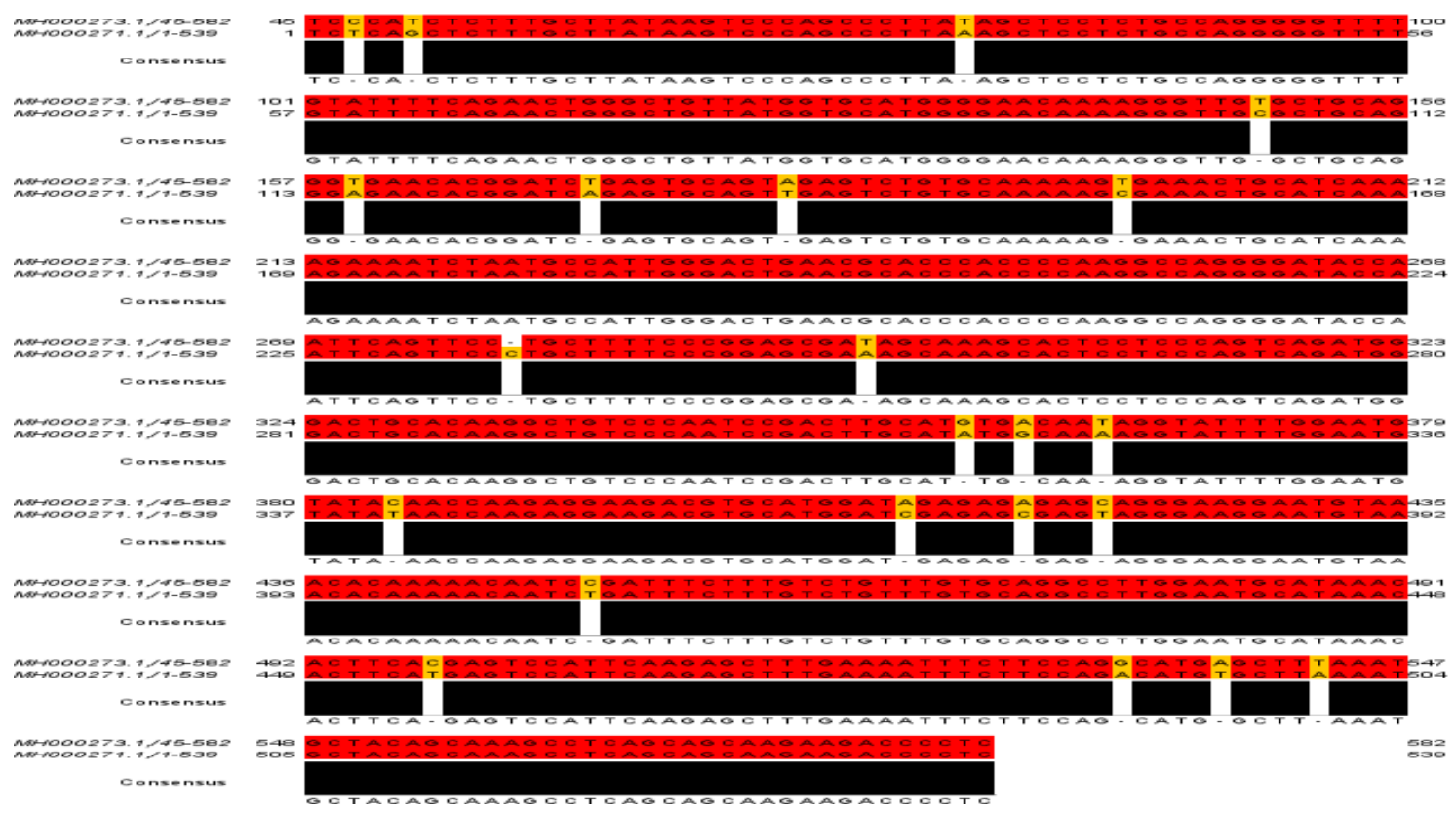

Fig. 4: Pairwise sequence alignment of $G A L 2$ gene between $\mathrm{R}$ breed and $1 / 2 \mathrm{R} 1 / 2 \mathrm{~F}$ cross.

A 664 bp product was amplified for gallinacin 3 genomic DNA sequence and many SNPs and gaps were identified between $F$ and $1 / 2 \mathrm{~F}^{1} / 2 \mathrm{R}$ with low identity ratio of $50 \%$, while 15 SNPs were identified between $F$ and $1 / 2 R^{1} / 2 F$ cross with high identity ratio of
98\%. The pairwise sequence alignment of $\mathrm{R}$ with $1 / 2 \mathrm{~F}^{1} / 2 \mathrm{R}$ cross showed that there was 38 SNPs and one gap with identity ratio of $94 \%$, while there were lot of SNPs and gaps with low identity ratio of $50 \%$ between $\mathrm{R}$ and $1 / 2 \mathrm{R} 1 / 2 \mathrm{~F}$ cross (Table 2 ). 


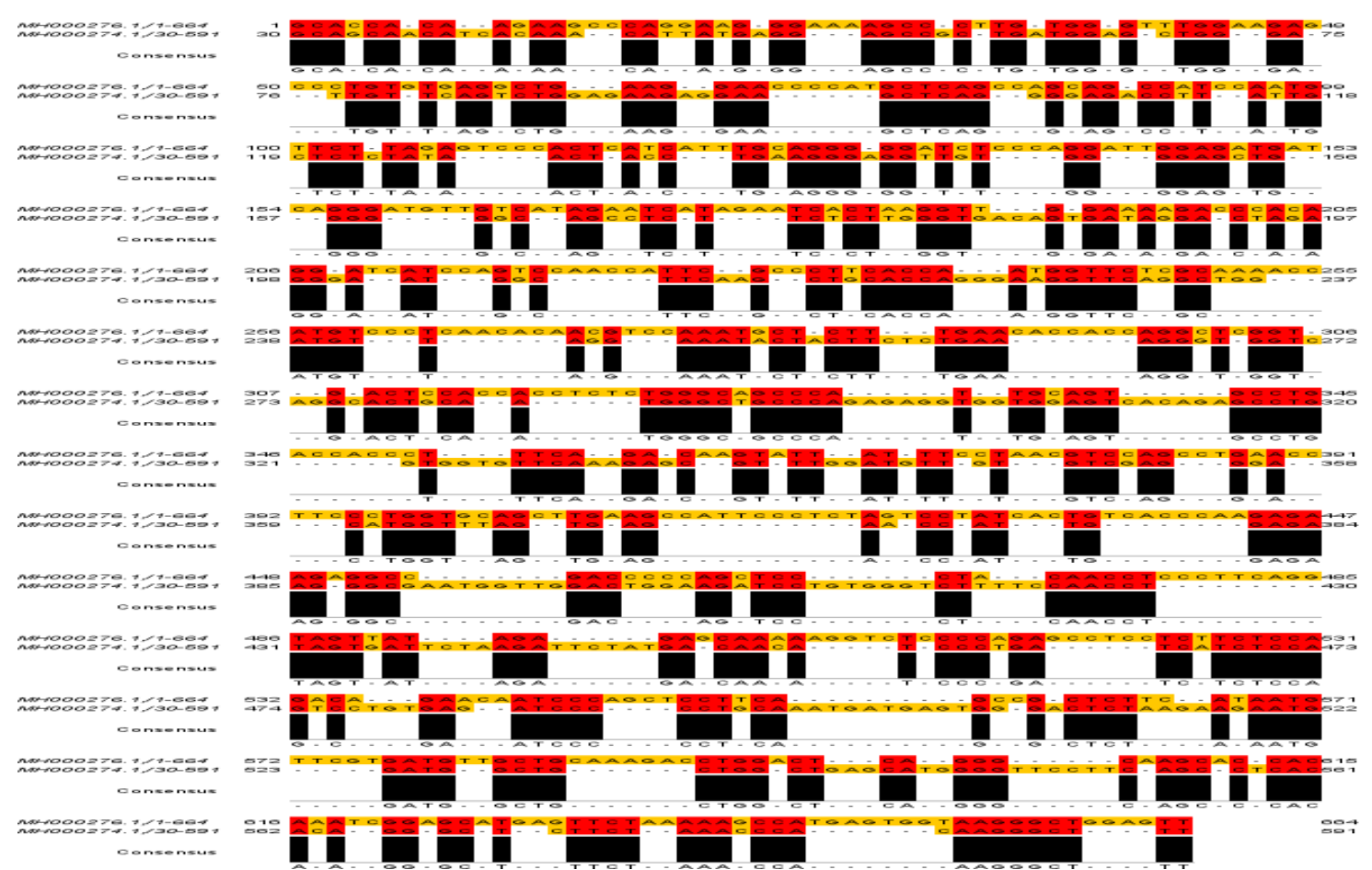

Fig. 5: Pairwise sequence alignment of $G A L 3$ gene between $\mathrm{F}$ breed and $1 / 2 \mathrm{~F}^{1} / 2 \mathrm{R}$ cross.

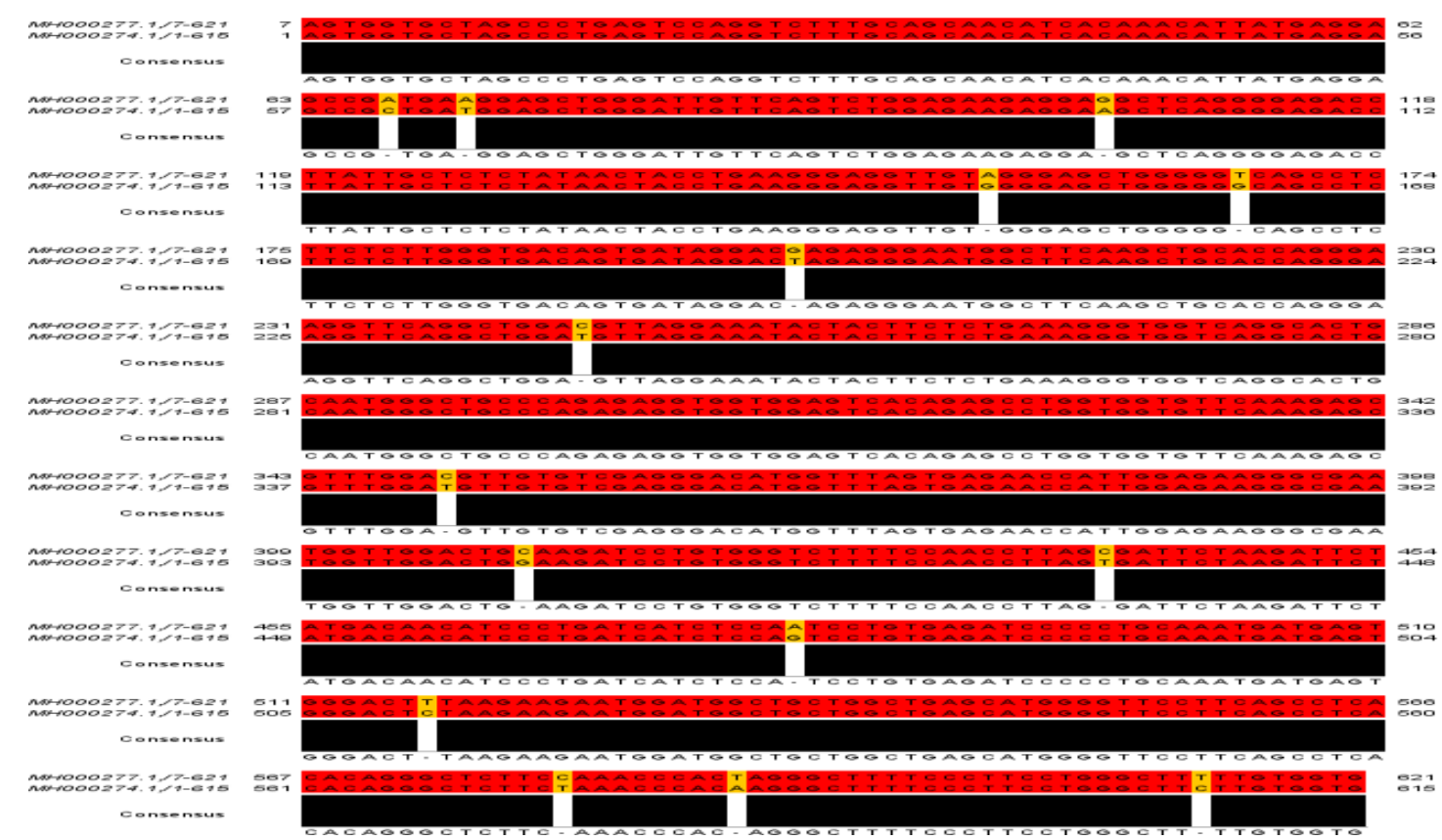

Fig. 6: Pairwise sequence alignment of $G A L 3$ gene between $F$ breed and $1 / 2 R^{1} 1 / 2 \mathrm{~F}$ cross. 


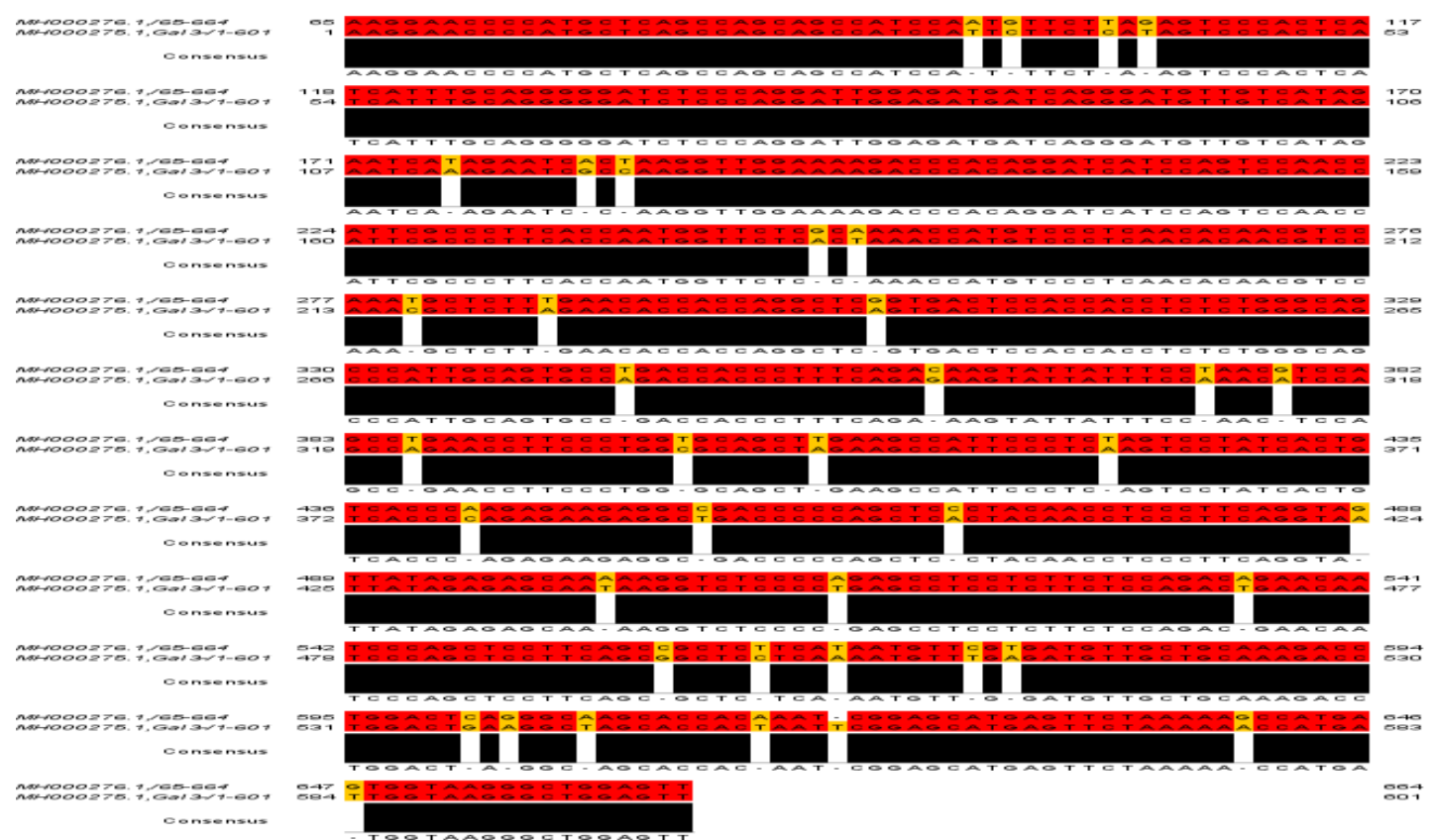

Fig. 7: Pairwise sequence alignment of GAL 3 gene between $\mathrm{R}$ breed and $1 / 2 \mathrm{~F}^{1} / 2 \mathrm{R}$ cross.
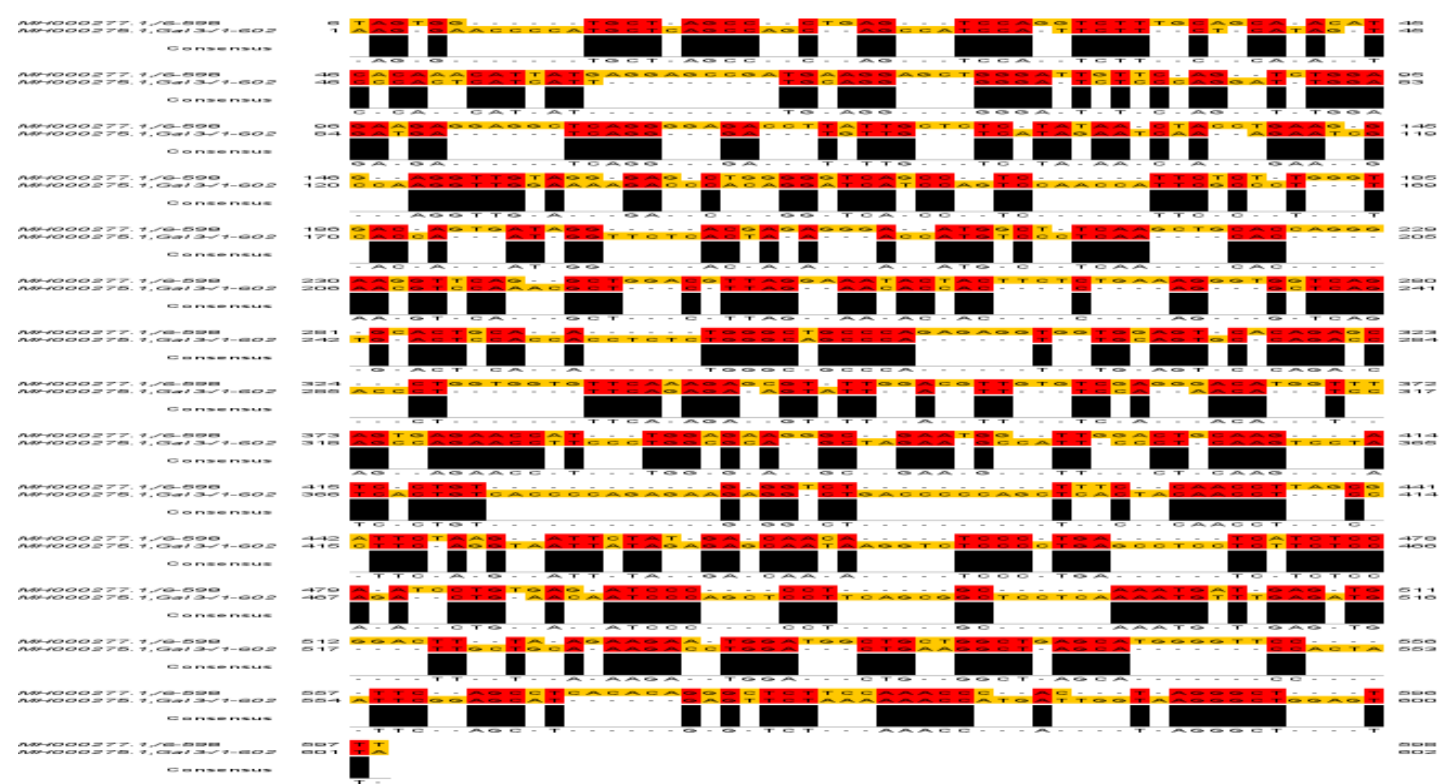

Fig. 8: Pairwise sequence alignment of GAL 3 gene between $\mathrm{R}$ breed and $1 / 2 \mathrm{R} 1 / 2 \mathrm{~F}$ cross.

Regarding the gallinacin 4 genomic DNA, a 600 bp product was amplified and ten SNPs and one gap were identified between $\mathrm{F}$ and $1 / 2 \mathrm{~F}^{1 / 2} \mathrm{R}$ cross with high identity ratio of $98 \%$ and 20 SNPs between $\mathrm{F}$ and
$1 / 2 \mathrm{R} 1 / 2 \mathrm{~F}$ cross with also high identity ratio of $96 \%$. The pairwise sequence alignment of $R$ with $1 / 2 \mathrm{~F}^{1} / 2 \mathrm{R}$ or $1 / 2 \mathrm{R} 1 / 2 \mathrm{~F}$ crosses showed that there were many SNPs and gaps with low identity ratio of $50 \%$ (Table 2 ). 


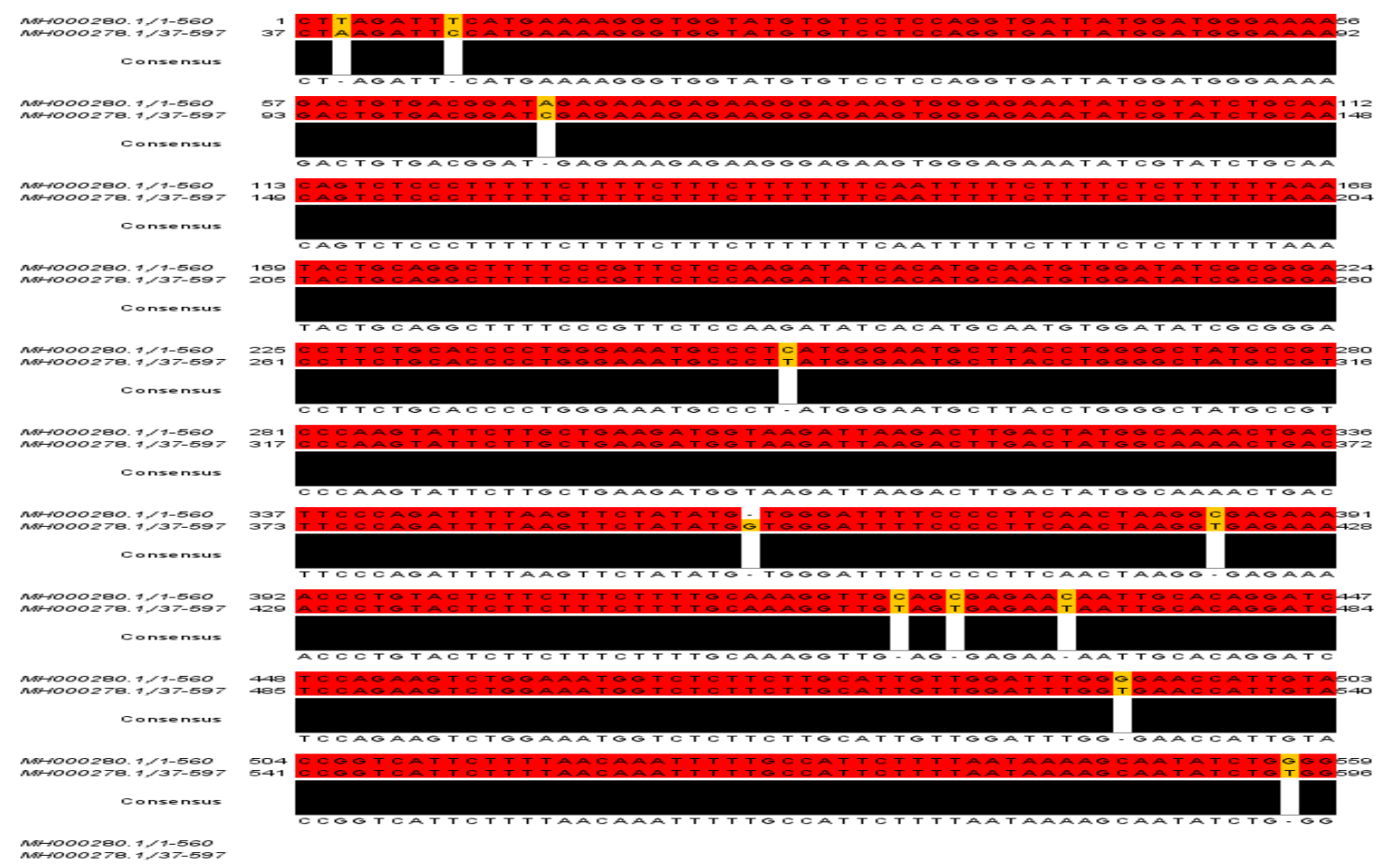

Fig. 9: Pairwise sequence alignment of $G A L 4$ gene between $\mathrm{F}$ breed and $1 / 2 \mathrm{~F}^{1} / 2 \mathrm{R}$ cross.

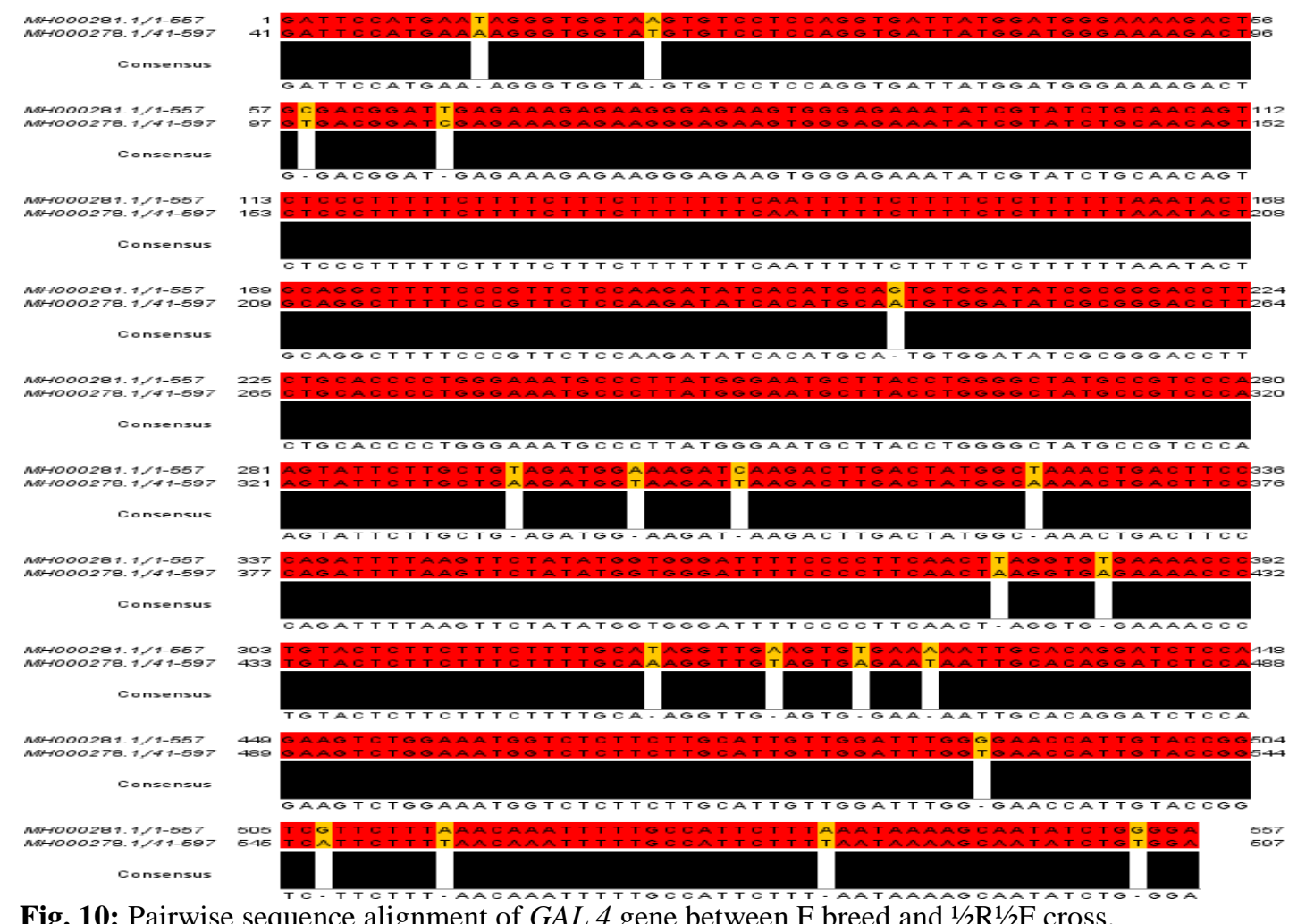

Fig. 10: Pairwise sequence alignment of $G A L 4$ gene between $F$ breed and $1 / 2 \mathrm{R} 1 / 2 \mathrm{~F}$ cross. 


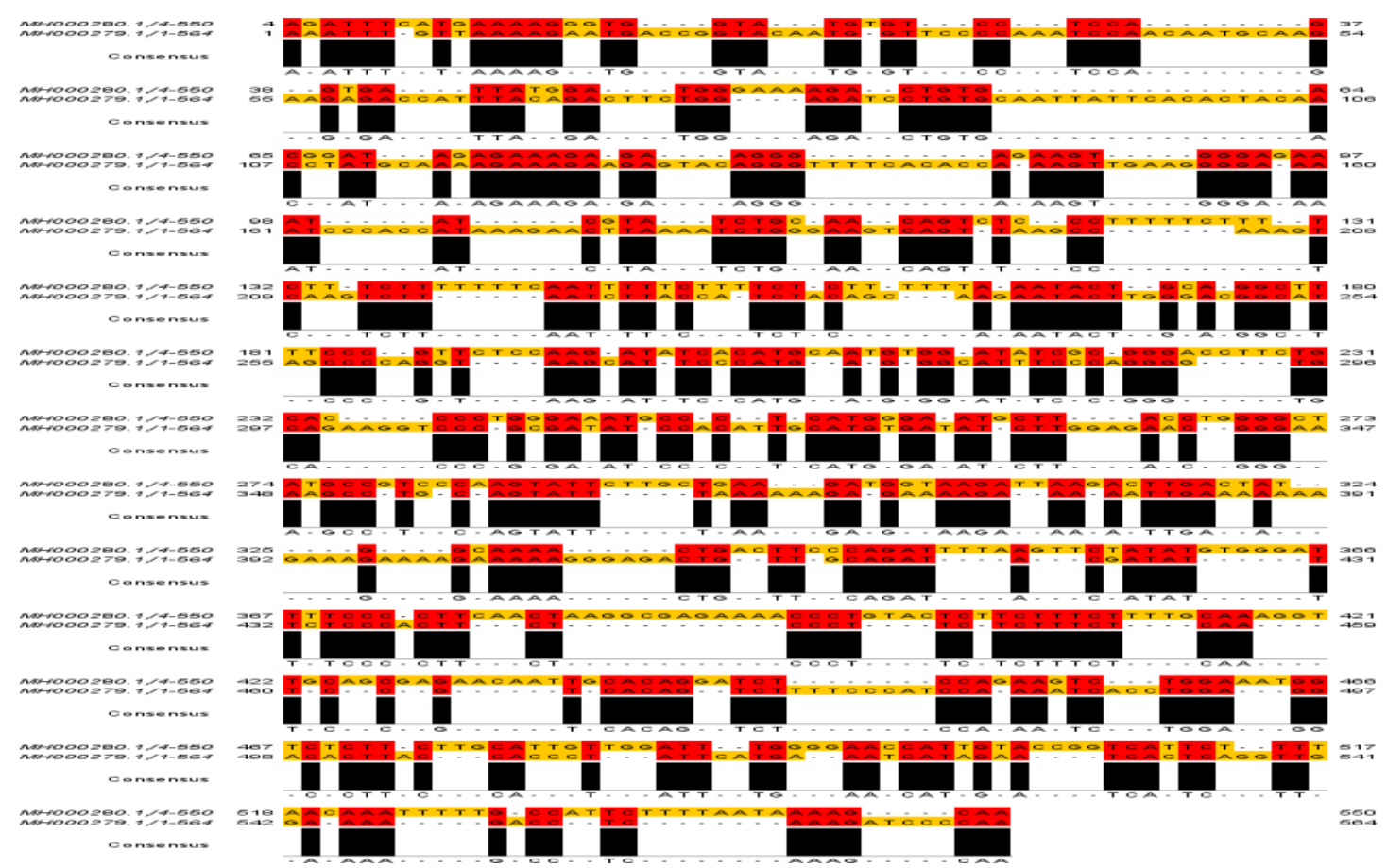

11: Pairwise sequence alignment of $G A L 4$ gene between $\mathrm{R}$ breed and $1 / 2 \mathrm{~F}^{1 / 2} \mathrm{R}$ cross.

Fig.

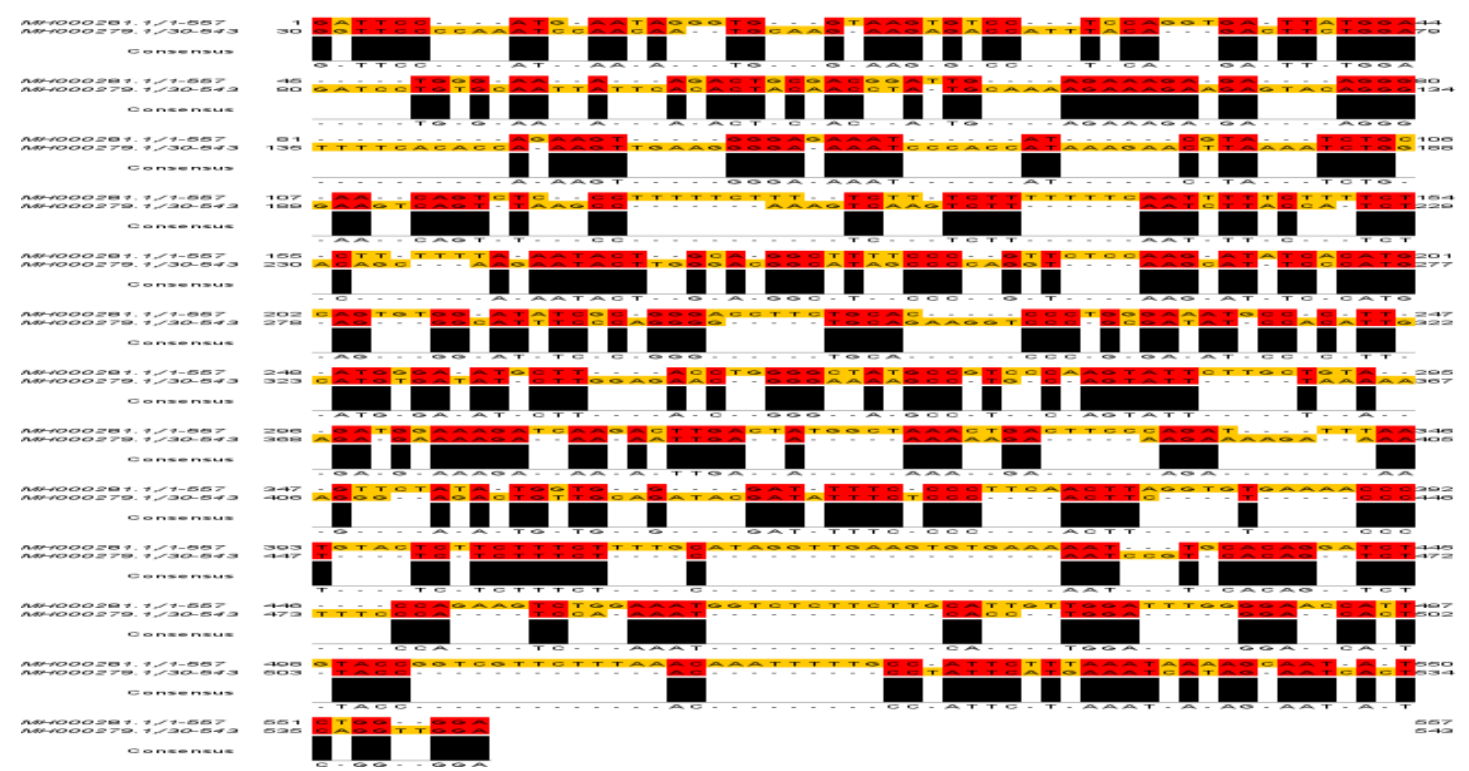

Fig. 12: Pairwise sequence alignment of $G A L 4$ gene between $\mathrm{R}$ breed and $1 / 2 \mathrm{R} 1 / 2 \mathrm{~F}$ cross.

A 623 bp product was amplified from gallinacin 5 genomic DNA, showing there were 18 SNPs between $\mathrm{F}$ and $1 / 2 \mathrm{~F}^{1} / 2 \mathrm{R}$ with high identity ratio of $97 \%$ and many SNPs and gaps between $F$ and $1 / 2 \mathrm{R} 1 / 2 \mathrm{~F}$ cross with low identity ratio of $50 \%$. The pairwise sequence showed also that there were 37 SNPs and two gaps between $\mathrm{R}$ and $1 / 2 \mathrm{~F}^{1} / 2 \mathrm{R}$ with high identity ratio of $90 \%$ and considerable numbers of SNPs and gaps with low identity ratio of $50 \%$ between $\mathrm{R}$ and $1 / 2 \mathrm{R} 1 / 2 \mathrm{~F}$ (Table 2 ). Yacoub et al. (2011) reported that the $G A L 3, G A L 4$, $G A L 5$ and GAL 10 genes were polymorphic because there were many (SNPs) in line 6 resistant and line 7 susceptible to Marek's Disease of White Leghorn chickens and some of these SNPs were located in intronic region and the rest were in exonic region. Hasenstein et al. (2006) found that a total of 43 SNPs were identified within the sequenced regions of $G A L$ 2, GAL 3, GAL 4, GAL 5 and GAL 7 with an SNP rate of 13.2 SNPs/kb, while Wong et al. (2004) reported lower SNP rate of $5 \mathrm{SNPs} / \mathrm{kb}$ across the entire chicken genome. However, with F1 generation from a cross between divergent breeds, substantial linkage disequilibrium exists. Therefore, it is not possible to determine if the SNPs identified in the present study are causal mutations or are in linkage with a causal mutation elsewhere in the gallinacin gene cluster. The chicken genome was sequenced and annotated (Hillier et al., 2004), and along with it, an SNP map 
consisting of 2.8 million SNPs was created (Wong $\boldsymbol{e t}$ al., 2004). This makes it possible to utilize the locations of known SNPs to fine-map a region of interest in the chicken genome.

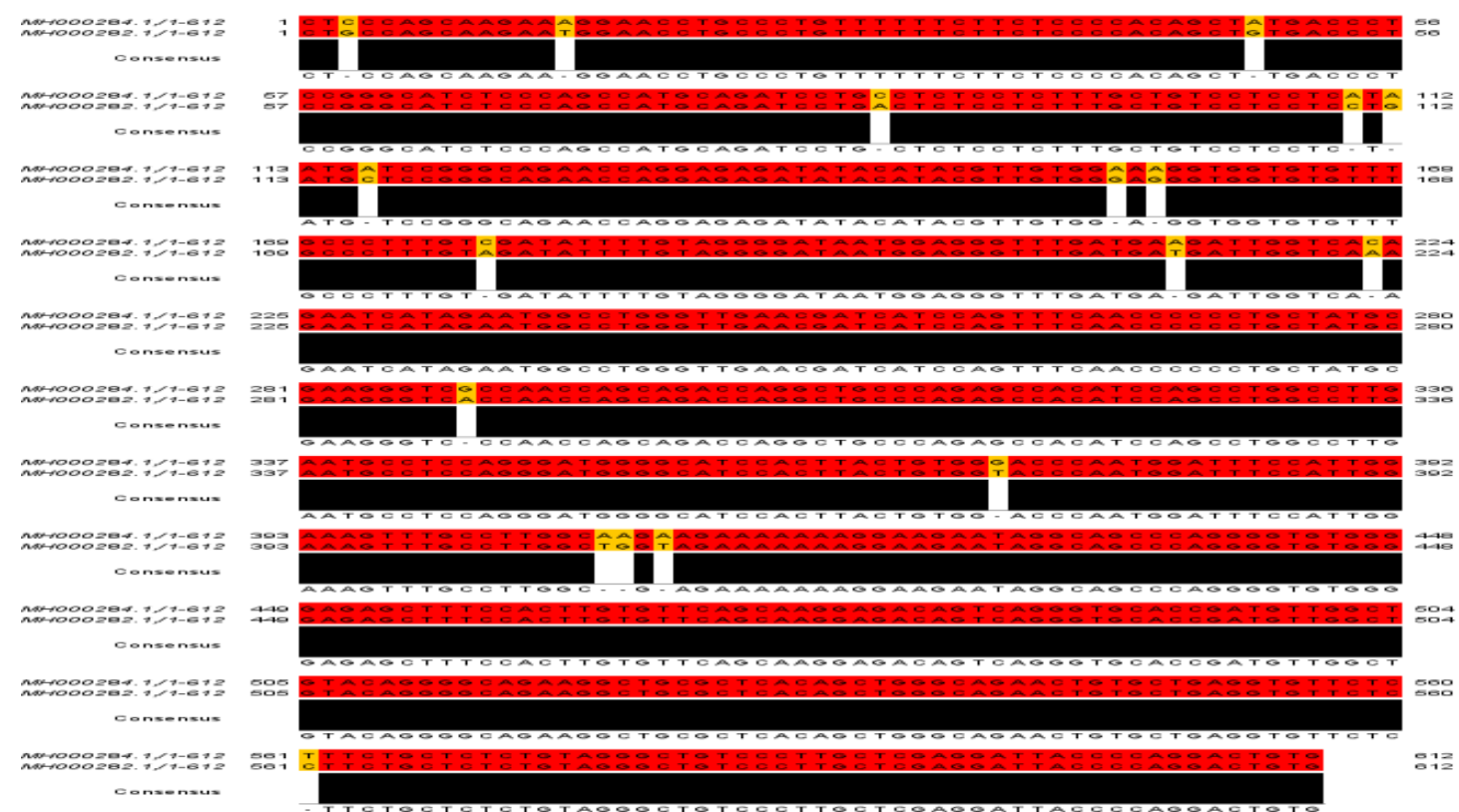

13: Pairwise sequence alignment of GAL 5 gene between $\mathrm{F}$ breed and $1 / 2 \mathrm{~F}^{1} / 2 \mathrm{R}$ cross.

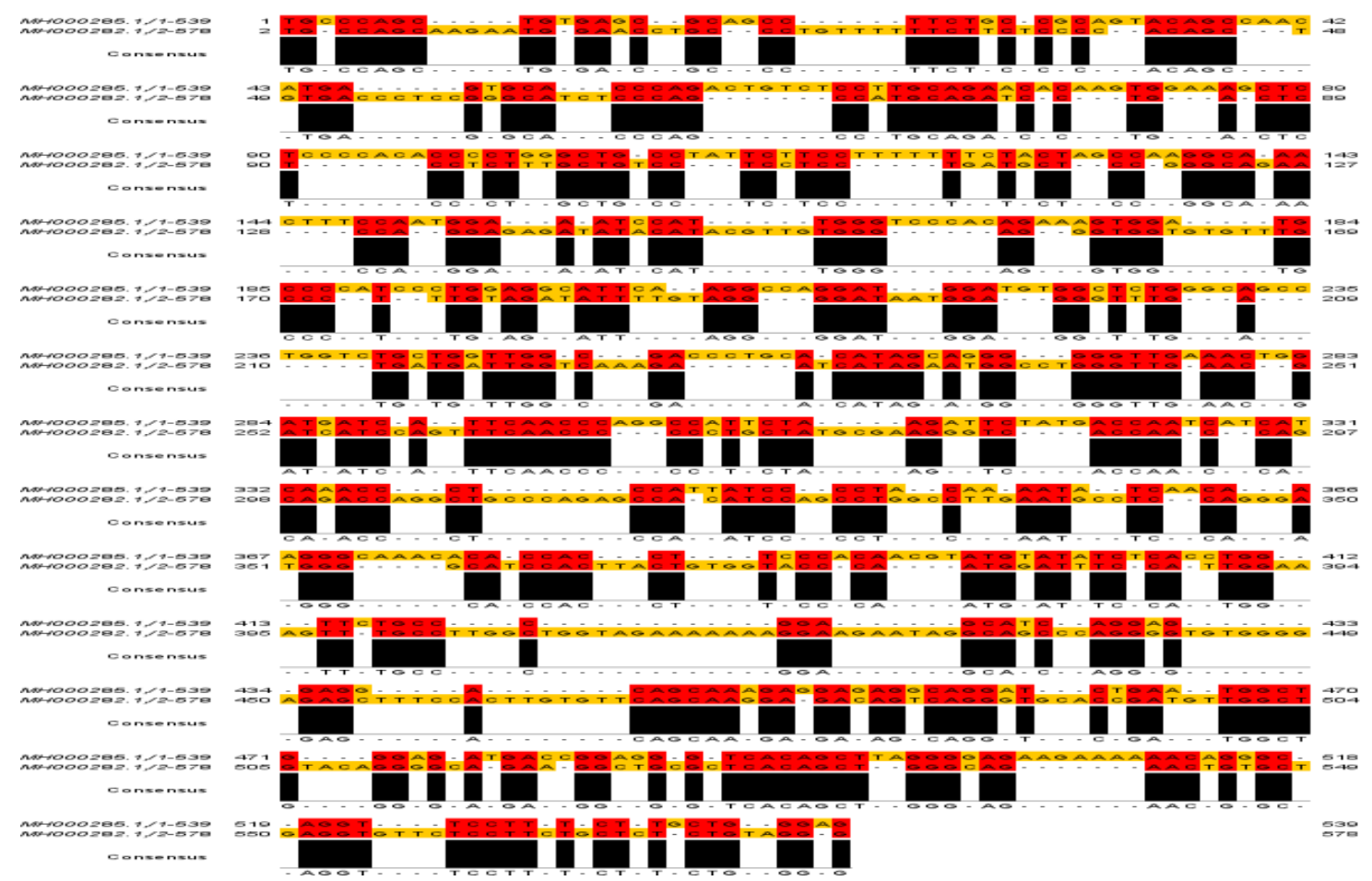

Fig. 14: Pairwise sequence alignment of $G A L 5$ gene between $F$ breed and $1 / 2 \mathrm{R} 1 / 2 \mathrm{~F}$ cross. 


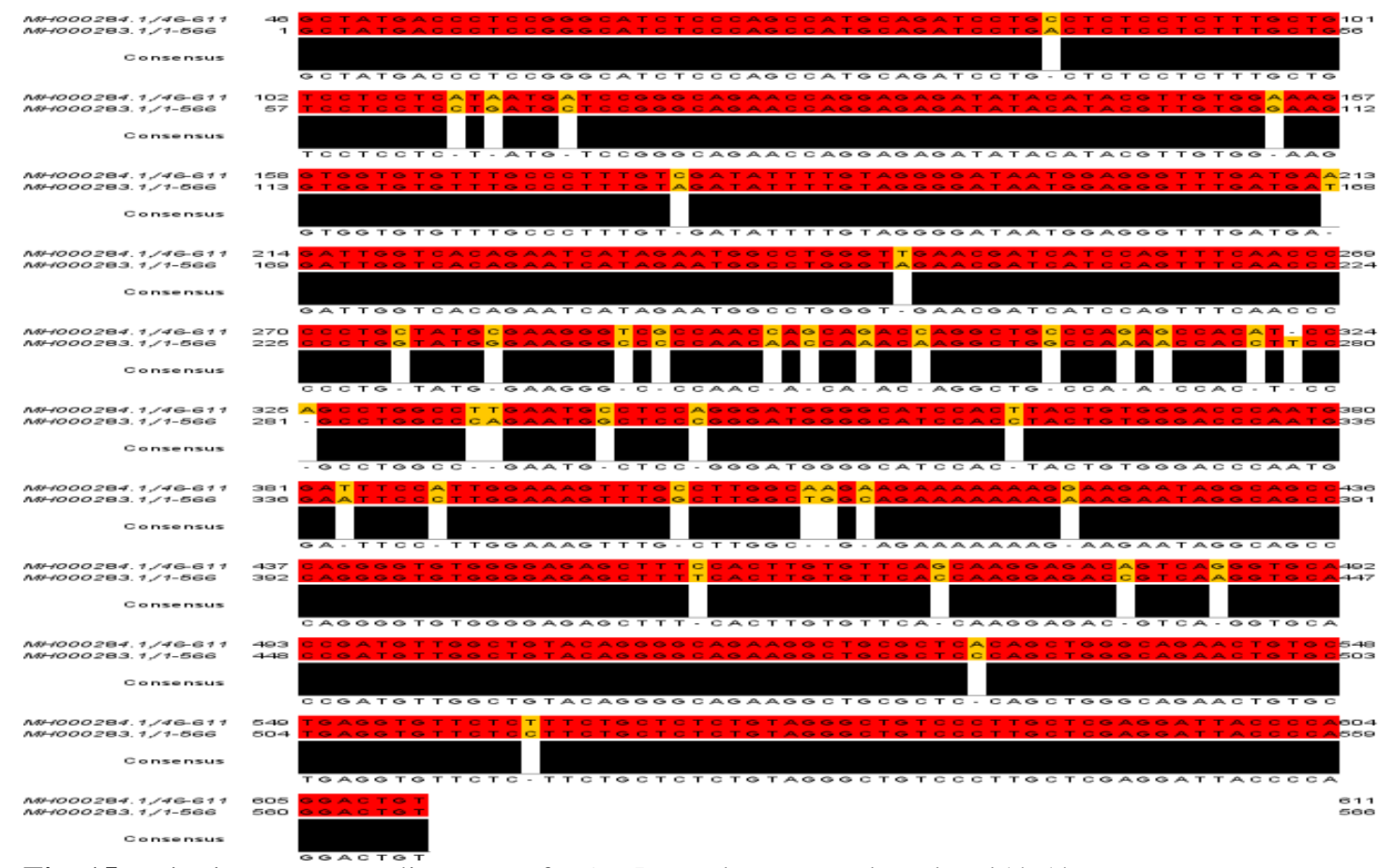

Fig. 15: Pairwise sequence alignment of GAL 5 gene between $\mathrm{R}$ breed and $1 / 2 \mathrm{~F}^{1} / 2 \mathrm{R}$ cross.

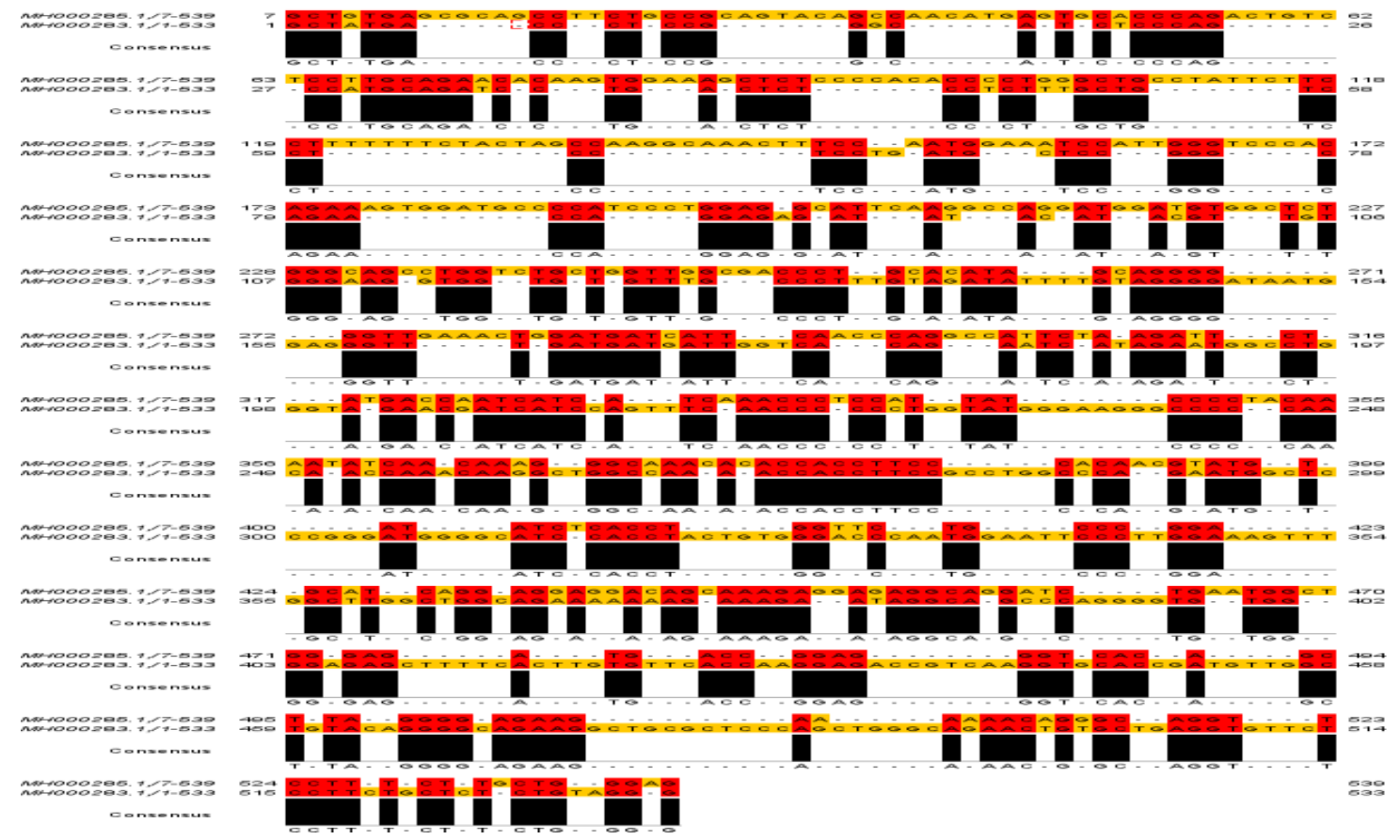

Fig. 16: Pairwise sequence alignment of GAL 5 gene between $\mathrm{R}$ breed and $1 / 2 \mathrm{R} 1 / 2 \mathrm{~F}$ cross.

In all Figures 1 up to 4 , the sequence variations for GAL 2, GAL 3, GAL 4 and GAL 5 genes in F, $\mathrm{R}, 1 \frac{1}{2} \mathrm{R} 1 / 2 \mathrm{~F}$ and $1 / 2 \mathrm{~F}^{1} / 2 \mathrm{R}$ indicate that there were many mutations or SNPs in $\mathrm{F}_{1}$ generation and the parental breeds, i.e. the genetic variations in sequences of $G A L$ genes are quite satisfactory for undertaking association studies and to know the causes of phenotypic variation and susceptibility to diseases in the studied genetic groups of chickens. Moreover, the nucleotide sequences analyzed here indicated that $G A L$ genes had many intronic mutations. Although these mutations in intronic regions did not affect the structure of protein molecules, they can provide excellent molecular markers in poultry breeding programs of genetic selection towards an increase in diseases immune responses (Morammazi and Habibi, 2017).

The high genetic variation in beta-defensin genes obtained in the present and other studies (Hasenstein et al., 2006; Morammazi and Habibi, 2017) have shown considerable roles in the innate immune 
response to gram-negative and gram-positive bacteria (Sugiarto and Yu, 2004; Higgs et al., 2005), an increase in resistance by enhancing the recruitment of macrophages, granulocytes, and lymphocytes of the infected tissues (Bar-Shira and Friedman, 2006), and an existence of genetic associations with immune response and bacterial loads (Hasenstein et al., 2006; Hasenstein and Lamont, 2007; van Dijk et al., 2008). This making the sequence variations of GAL genes in the genetic groups are promising genetic markers in assisting of chickens selection programs.

\section{Conclusions}

Based on DNA sequencing, variations in $G A L$ genes can be employed potentially in marker-assisted selection programs. Therefore, the GAL 3 and GAL 5 genes could be used as genetic markers in selection programs to improve the genetic immune response against Salmonella in chickens.

The sequence of gallinacin genes had many mutations present in intronic regions which opens up more prospects for associations and responses to pathogens studies that may help in development of a PCR genotyping test to select the parents with better immunity.

\section{Acknowledgments}

The authors would like to thank the European Union Commission, that partially funded this Joint Master Degree of TEMPUS program (Project No. 543865). The authors are gratefully acknowledge the support and help of members of Research Labs Park and Labs of Genetics Department, Faculty of Agriculture, Benha University, Egypt, and Molecular Biology Labs of Avian Pathology Section, Department of Veterinary Medicine, University of Bari, Italy.

\section{References}

Abd El-Ghany, W.A., Abd El-Shafii, S.S. and Hatem, M. 2012. A survey on Salmonella species isolated from chicken flocks in Egypt. Asian Journal of Animal and Veterinary Advances, 7, 489-501.

Ammar, A., Ahmed, Y., Asawy, A. and Ibrahim, A. 2009. Bacteriological studies on Salmonella enteritidis isolated from different sources in Dakhlia Governorate. Assiut Veterinary Medical Journal, 56, 125-135.

Bar-Shira, E. and Friedman, A. 2006. Development and adaptations of innate immunity in the gastrointestinal tract of the newly hatched chick. Developmental and Comparative Immunology, 30, 930-941.

El-Safey, E. 2013. Incidence of Salmonella heidelberg in some Egyptian food. International Journal of Microbiology and Immunology Research, 1, 16-25.
Friedman, A., Bar-Shira, E. and Sklan, D. 2003. Ontogeny of gut associated immune competence in the chick. World's Poultry Science Journal, 59, 209-219.

Ganz, T. 2003. Defensins: antimicrobial peptides of innate immunity. Nature Reviews Immunology, 3, 710-720.

Hasenstein, J.R and Lamont, S. 2007. Chicken gallinacin gene cluster associated with Salmonella response in advanced intercross line. Avian Dseases, 51, 561-567.

Hasenstein, J.R., Zhang, G. and Lamont, S.J. 2006. Analyses of five gallinacin genes and the Salmonella enterica serovar Enteritidis response in poultry. Infection and Immunity, 74, 3375-3380.

Higgs, R., Lynn, D.J., Gaines, S., Mcmahon, J., Tierney, J., James, T., Lloyd, A.T., Mulcahy, G. and O'farrelly, C. 2005. The synthetic form of a novel chicken $\beta$-defensin identified in silico is predominantly active against intestinal pathogens. Immunogenetics, 57, 90-98.

Hillier, L. W., Miller, W., Birney, E., Warren, W., Hardison, R. C., Ponting, C. P., Bork, P., Burt, D. W., Groenen, M. A., Delany, M. E., Dodgson, J. B., Chinwalla, A. T., Cliften, P. F., Clifton, S. W., Delehaunty, K. D., Fronick, C., Fulton, R. S., Graves, T. A., Kremitzki, C., Layman, D., Magrini, V., McPherson, J. D., Miner, T. L., Minx, P., Nash, W. E., Nhan, M. N., Nelson, J. O., Oddy, L. G., Pohl, C. S., Randall-Maher, J., Smith, S. M., Wallis, J. W., Yang, S. P., Romanov, M. N., Rondelli, C. M., Paton, B., Smith, J., Morrice, D., Daniels, L., Tempest, H. G., Robertson, L., Masabanda, J. S., Griffin, D. K., Vignal, A., Fillon, V., Jacobbson, L., Kerje, S., Andersson, L., Crooijmans, R. P., Aerts, J., van der Poel, J. J., Ellegren, H., Caldwell, R. B., Hubbard, S. J., Grafham, D. V., Kierzek, A. M., McLaren, S. R., Overton, I. M., Arakawa, H., Beattie, K. J., Bezzubov, Y., Boardman, P. E., Bonfield, J. K., Croning, M. D., Davies, R. M., Francis, M. D., Humphray, S. J., Scott, C. E., Taylor, R. G., Tickle, C., Brown, W. R., Rogers, J., Buerstedde, J. M., Wilson, S. A., Stubbs, L., Ovcharenko, I., Gordon, L., Lucas, S., Miller, M. M., Inoko, H., Shiina, T., Kaufman, J., Salomonsen, J., Skjoedt, K., Wong, G. K., Wang, J., Liu, B., Yu, J., Yang, H., Nefedov, M., Koriabine, M., Dejong, P. J., Goodstadt, L., Webber, C., Dickens, N. J., Letunic, I., Suyama, M., Torrents, D., von Mering, C. and Zdobnov, E. M. 2004. Sequence and comparative analysis of the chicken genome provide unique perspectives on vertebrate evolution. Nature 432: 695-716.

Kramer, J., Malek, M., and Lamont, S.J. 2003. Association of twelve candidate gene

polymorphisms and response to challenge with Salmonella enteritidis in poultry. Animal Genetics, 34, 339-348. 
Lai, Y., and Gallo, R.L. 2009. AMPed up immunity: how antimicrobial peptides have multiple roles in immune defense. Trends Immunol., 30, 131-141.

Morammazi, S. and Habibi, H. 2017. Sequence Variation in GAL1 and GAL2 Genes in Khuzestan Local Chickens. European Online Journal of Natural and Social Sciences, 6, 508-515.

NRC. 1994. National research council nutrient requirements of poultry-Nine ${ }^{\text {th }}$ revised edition. Journal of Applied Poultry Research, 3, 101.

Pruthviraj, D.R., Usha, A.P., and Venkatachalapathy, R.T. (2016). Identification of a novel single nucleotide polymorphism in Porcine beta-defensin-1 gene. Asian-Australas J Anim Sci., 29, 315-320.

Rothschild, M. 1997. Candidate gene analysis to detect genes controlling traits of economic importance in domestic livestock. Probe Newsletter for Agriculture Genomic, 8, 13-20.

Saleh, M. S. 2019. Using bioinformatics SNP to improve immune genetic response against some pathogens in poultry. M Sc. thesis in cooperation between Faculty of Agriculture at Moshtohor, Benha University and TEMPUS European Union program, Egypt

Saleh, M. S., Iraqi, M. M., Khalil, M. H., and Camarda, A. (2020). Crossbreeding analyses and polymorphic associations of gallinacin genes with growth traits in chickens. Livestock Science, 104118. doi:10.1016/j.livsci.2020.104118

Sugiarto, H. and Yu, P.L. 2004. Avian antimicrobial peptides: the defense role of $\beta$-defensins. Biochemical and Biophysical Research Communications, 323, 721-727.

Van Dijk, A., Veldhuizen, E.J. and Haagsman, H.P. 2008. Avian Defensins. Veterinary Immunology and Immunopathology, 124, 1-18.

Wakchaure, R., Ganguly, S., Praveen, P., Kumar, A., Sharma, S. and Mahajan, T. 2015. Marker assisted selection (MAS) in animal breeding: A review. Journal of Drug Metabolism and Toxicology, 6, 127-130.

Wong, G., Liu, B., Wang, J., Zhang, Y., Yang, X., Zhang, Z., Meng, Q., Zhou, J., Li, D., Zhang, J., Ni, P., Li, S., Ran, L., Li, H., Li, R., Zheng, H., Lin, W., Li, G., Wang, X., Zhao, W., Li, J., Ye, C., Dai, M., Ruan, J., Zhou, Y., Li, Y., He, X., Huang, X., Tong, W., Chen, J., Ye, J., Chen, C., Wei, N., Dong, L., Lan, F., Sun, Y., Yang, Z., Yu, Y., Huang, Y., He, D., Xi, Y., Wei, D., Qi, Q., Li, W., Shi, J., Wang, M., Xie, F., Zhang, X., Wang, P., Zhao, Y., Li, N., Yang, N., Dong, W., Hu, S., Zeng, C., Zheng, W., Hao, B., Hillier, L. W., Yang, S. P., Warren, W. C., Wilson, R. K., Brandstrom, M., Ellegren, H., Crooijmans, R. P., van der Poel, J. J., Bovenhuis, H., Groenen, M. A., Ovcharenko, I., Gordon, L., Stubbs, L., Lucas, S., Glavina, T., Aerts, A., Kaiser, P., Rothwell, L., Young, J. R., Rogers, S., Walker, B. A., van Hateren, A., Kaufman, J., Bumstead, N., Lamont, S. J., Zhou, H., Hocking, P. M., Morrice, D., de Koning, D. J., Law, A., Bartley, N., Burt, D. W., Hunt, H., Cheng, H. H., Gunnarsson, U., Wahlberg, P., Andersson, L., Institutet, K., Kindlund, E., Tammi, M. T., Andersson, B., Webber, C. and Ponting, C. P. 2004. A genetic variation map for chicken with 2.8 million single nucleotide polymorphisms. Nature 432:717-722.

Xiao, Y., Hughes, A.L., Ando, J., Matsuda, Y., Cheng, J.F., Skinner-Noble, D. and Zhang, G. 2004. A genome-wide screen identifies a single $\beta$ defensin gene cluster in the chicken: implications for the origin and evolution of mammalian defensins. BMC Genomics, 5, 56-66.

Yacoub, H.A., Galal, A., Fathi, M.M., El Fiky, S.A. and Ramadan, H.A. 2011. Association between candidate genes of innate immunity, gallinacin genes and resistance to Marek's disease in chicken. International Journal of Poultry Science, 10(8):656-661. 